\title{
Martwica bifosfonianowa kości szczęk - przegląd piśmiennictwa i opis przypadków
}

\section{Bisphosphonate necrosis of the jaws - a literature review and case reports}

\author{
Oddział Chirurgii Szczękowo-Twarzowej, Radomski Szpital Specjalistyczny im. dr Tytusa Chałubińskiego
}

DOI: http://dx.doi.org/10.20883/df.2017.30

\begin{abstract}
Streszczenie
Wprowadzenie. Bifosfoniany należą do popularnych leków, mających zastosowanie jako uzupełniająca grupa w terapii chorób kości. Ze względu na brak ujednoliconego sposobu postępowania z chorymi podjęto próbę leczenia na podstawie doświadczeń własnych.

Cel. Celem pracy była ocena przebiegu procesu gojenia u pacjentów poddanych terapii bifosfonianami.

Materiał i metody. Dwóch chorych przyjęto i leczono ambulatoryjnie. Chory A.G. leczony przy wykorzystaniu ozonoterapii, chory J.P. leczony chirurgicznie (oczyszczenie rany, mobilizacja brzegów dziąsła i szycie szczelne).

Wyniki. W obu przypadkach otrzymano satysfakcjonujące efekty terapeutyczne. Przedstawione wyniki wskazują na potrzebę połączenia metod zabiegowych z prawidłową opieką pozabiegową.

Wnioski. 1) Sposób postępowania z chorym w trakcie terapii lekami z grupy bifosfonianów powinien uwzględniać stan miejscowy. 2) W trakcie przygotowywania chorego należy uwzględnić zasadę proporcjonalności, samą procedurę medyczną oraz możliwy do uzyskania efekt terapeutyczny. 3) Ze względu na brak ujednoliconego postępowania terapeutycznego należy brać pod uwagę wiele innych czynników mogących mieć wpływ na wynik leczenia, gdzie kluczowym wydaje się być zespołowe przygotowanie i prowadzenie chorego.
\end{abstract}

Słowa kluczowe: bifosfoniany, martwica kości szczęk, leczenie martwicy kości.

\begin{abstract}
Introduction. Bisphosphonates are common medicinal products used as an adjunct group in therapies of bone disease. Due to the lack of uniform management of patients with such a health problem, we provided treatment based on our own clinical experience.

Aim. The purpose of this paper was to evaluate the healing process in patients on a therapy with bisphosphonates.

Material and Methods. Two patients received ambulatory treatment. One of them was treated with ozone, while the other was treated surgically (debridement, tissue mobilization and suturing)

Results. Both cases had successful outcomes, which demonstrated the necessity of combining surgery with proper postoperative care.

Conclusions. 1) The course of treatment with bisphosphonates should take into account local conditions. 2) The preparation of the patient for therapy should involve the application of the proportionality principle and consideration of a potential therapeutic effect. 3) As no uniform therapeutic protocol exists, a number of factors may affect the outcome, which depends on the interdisciplinary preparation of the patient and proper treatment management.
\end{abstract}

Keywords: bisphosphonates, osteonecrosis of jaws, treatment of bone necrosis.

\section{Wstęp}

Leki z grupy bifosfonianów (BP, ang. bisphosphonate) mają coraz szersze zastosowanie, szczególnie u osób z chorobami rozrostowymi (np. szpiczaka mnogiego) i przerzutami nowotworowymi do tkanki kostnej (w tym raka płuc, piersi lub prostaty), jak również w przypadku stwierdzenia osteoporozy ( $w$ tym indukowanej glukokortykosterydami lub unieruchomieniem), choroby Pageta, hiperkalcemii spowodowanej różnymi czynnikami, choroby osteogenesis imperfecta, spadku gęstości kości (np. u dzieci) w przypadku stwierdzenia wrodzonego zaburzenia polegającego na mutacji w genie dla kolagenu typu I [1-3]. W trakcie terapii bifosfonianami wykazano ich szczególne powino- wactwo do tkanki kostnej rejonu szczękowo-twarzowego [4].

Jednak leki tej grupy mają swój negatywny wpływ na zdrowie człowieka. Od ponad 2 dekad u osób stosujących bifosfoniany obserwuje się martwicę kości, zwiększone ryzyko groźnego dla życia migotania przedsionków (ang. atrial fibrillation - AF), nadmierne zahamowanie metabolizmu kości na poziomie komórkowym (ang. turnover) w obrębie kości prowadzące do objawów „zamrożenia kości” (ang. frozen bone). „Zamrożenie kości" charakteryzuje się upośledzoną zdolnością naprawy mikrozłamań i zwiększoną wrażliwością kości na urazy. Obserwuje się również hipokal- 
cemię, znaczne dolegliwości bólowe mięśniowo-szkieletowe oraz ostrą odpowiedź zapalną. Ostra odpowiedź zapalna dotyczy od $10-30 \%$ chorych leczonych lekami z grupy bifosfonianów i najczęściej wiązana jest $z$ grupą leków zawierającą w swoim składzie atom azotu (np.: kwas zoledronowy). Samo zapalenie manifestuje się przemijającą gorączką z bólem mięśniowym, bólem stawowym, bólami głowy i objawami grypopodobnymi [3]. Obecnie obserwuje się (według różnych źródeł) do 18\% martwicy kości szczęk u pacjentów przyjmujących bifosfoniany (bisfosonianozależna martwica kości szczęk, ang. bisphosphonate-related osteonecrosis of the jaw - BRONJ) [5]. Martwica kości szczęk (ang. osteonecrosis of the jaw - ONJ) jest opisywana jako miejscowa ekspozycja martwej tkanki kostnej trwająca minimum 8 tygodni, bez objawów bólowych, infekcji, poprzedzającego urazu lub radioterapii w wywiadzie $[1,6,7]$.

Amerykańskie Towarzystwo Chirurgów Stomatologicznych i Szczękowo-Twarzowych (ang. American Association of Oral and Maxillofacial Surgeons - AAOMS) podzieliło bifosfonianozależną martwicę kości na 3 stadia $[1,2,7]$ :

Stadium 1 - kość widoczna/martwa w jamie ustnej, niepokryta błoną śluzową, bez objawów prodromalnych lub objawów infekcji;

Stadium 2 - kość widoczna/martwa w jamie ustnej $z$ dodatkowo występującymi objawami takimi jak ból, zaczerwienienie, obrzęk tkanek otaczających wskazujących na istnienie miejscowej infekcji bez współistniejącego drenażu ropnego;

Stadium 3 - kość widoczna/martwa w jamie ustnej z współistniejącym bólem, infekcją miejscową oraz jednym lub więcej objawów współistniejących takich jak: złamanie patologiczne, obecność przetoki zewnątrzustnej, lizy kostnej sięgającej do dolnej granicy ubytku dotkniętego zmianą chorobową.

\section{Bifosfoniany}

Bifosfoniany należą do grupy pochodnych kwasu bifosfoniowego. Gromadzą się w zmineralizowanej przestrzeni międzykomórkowej kości, a mając powinowactwo do wapnia tworzą wieloogniskowe kompleksy. Ograniczają aktywność osteoklastów, przez co hamują resorpcję kości [2]. Poprzez zmniejszanie we krwi stężenia czynnika wzrostu śódbłonka naczyniowego (ang. vascular endothelial growth factor - VEGF), mają także działanie hamujące angiogenezę. Stosowane są podczas leczenia chorób powodujących zmniejszenie gęstości kości, takich jak wspomniana osteoporoza, choroba Pageta, stany hiperkalcemii wywołane nadczynnością gruczołów przytarczycznych, no- wotwory kości ze znacznym zwiększeniem aktywności fosfatazy alkalicznej we krwi. Ograniczają występującą przy nowotworach kości osteolizę i hiperkalcemię poprzez zmniejszenie adhezji komórek nowotworowych do macierzy kostnej. Leki tej grupy słabo wchłaniają się z przewodu pokarmowego. Podaje się je w tabletkach lub kapsułkach, a przy hiperkalcemii nowotworowej - podawane są co 3-4 tygodnie we wlewie dożylnym (kwas pamidronowy, kwas zoledronowy, kwas ibandronowy) lub doustnie (kwas klodronowy, kwas aledronowy). Do działań niepożądanych należą: podrażnienia przewodu pokarmowego, biegunki, nudności i wymioty. W dużych dawkach obserwuje się opóźnienie zrostu kości oraz złamania. Zjawisko to jest tłumaczone znaczną kruchością tkanki i mniejszą odpornością na obciążenia [1, 8].

\section{Cel}

Celem pracy była ocena przebiegu procesu gojenia u pacjentów poddanych terapii bifosfonianami.

\section{Materiał i metody}

Do Poradni Chirurgii Szczękowo-Twarzowej Radomskiego Szpitala Specjalistycznego zgłosiło się dwóch chorych.

Chora A.G. lat 70 zgłosiła się z powodu powtarzających się epizodów wydzielania martwaków ze szczęki, z okolicy zębodołów zębów 14, 15 (ekstrakcje wykonane $w$ trakcie terapii $z$ użyciem leków z grupy bifosfonianów). W wywiadzie stan obserwowany przez chorą od kilku miesięcy, $z$ umiarkowanym nasileniem, bez objawów ogólnych. Z wydzielaniem martwaków kostnych (wielkość kilku milimetrów) chora zgłaszała dolegliwości bólowe, zaczerwienienie i obrzmienie błony śluzowej dziąsła. Chora użytkuje protezę całkowitą górną i dolną.

W historii choroby stwierdzono przewlekłe leczenie osteoporozy z wykorzystaniem bifosfonianów.

W badaniu klinicznym stwierdzono obecność przetoki w przedsionku szczęki przy bezzębiu całkowitym. W porozumieniu z lekarzem prowadzącym zalecono odstawienie bifosfonianów, wykonanie nowych protez całkowitych oraz zakwalifikowano do leczenia zachowawczego. Przez 5 kolejnych dni przeprowadzano ozonowanie przetoki (urządzenie Ozonytron X firmy Mymed) i okolicznych tkanek równolegle stosując pastę Solcoseryl w tej samej okolicy. Następnie zastosowano 14 dni przerwy od ozonoterapii nieprzerwanie stosując Solcoseryl. Po tym czasie ponownie włączono ozonoterapię na 5 kolejnych dni. Po tym czasie uzyskano zdecydowaną poprawę stanu miejscowego z zamknięciem przetoki. Zalecono okresowe kontrole. 


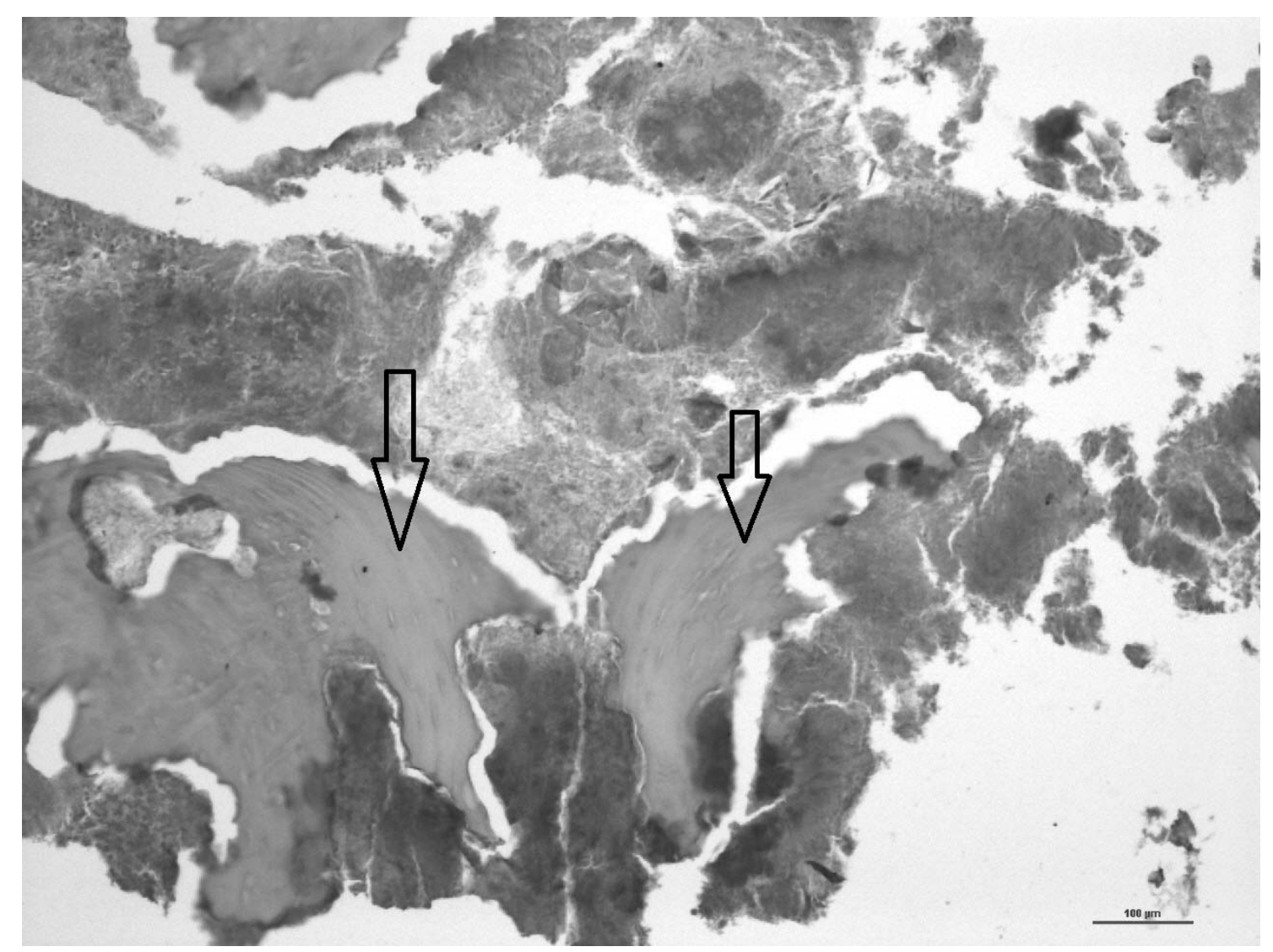

Rycina 1. Preparat martwej kości (strzałki), skala barwienie hematoksyliną-eozyną, powiększenie 100x

Figure 1. Microscopic specimen of necrotic bone (arrows), haematoxylin and eosin staining, magnification 100x

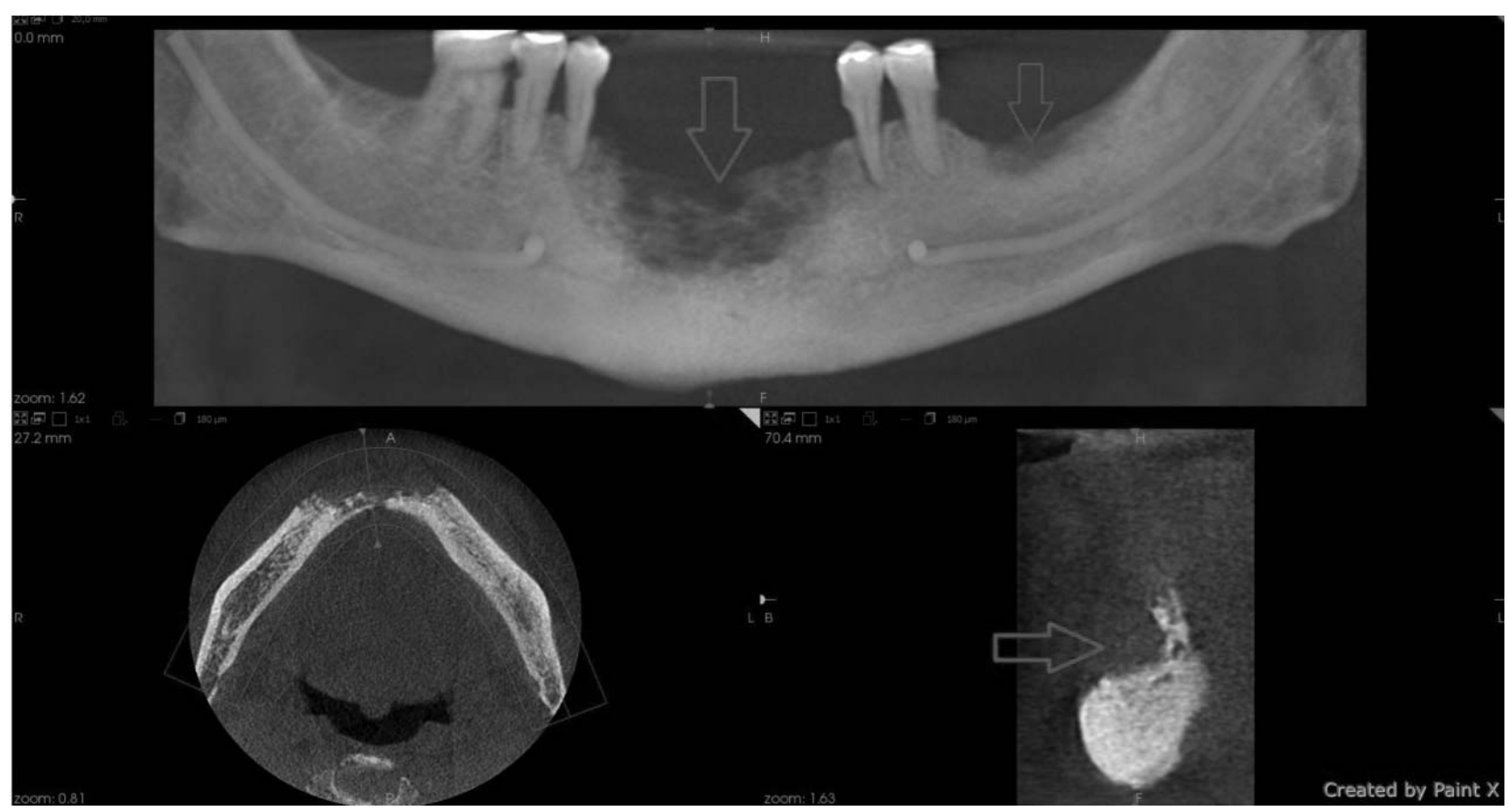

Rycina 2. Stożkowa wiązka tomografii komputerowej (CBCT) żuchwy, widoczny fragment martwej kości (strzałki) Figure 2. Cone Beam Computer Tomography (CBCT) of the mandibule, part of necrotic bone (arrows)

Po 2 miesiącach pacjentka zgłosiła się z powodu wydzielającego się kolejnego fragmentu kości w sąsiedniej o $1 \mathrm{~cm}$ okolicy. Usunięto fragment kostny w osłonie antybiotykowej po czym uzyska- no szybkie zamknięcie rany. Z uzyskanego materiału wykonano preparat histopatologiczny (Rycina 1). Obecnie pacjentka pozostaje od 6 mies. pod obserwacją bez dolegliwości. 
Chory J.P. zgłosił się do Poradni z niegojącą się raną od kilku miesięcy. W wywiadzie: rana w przednim odcinku części zębodołowej żuchwy (Rycina 2) zaobserwowana 6 miesięcy temu, o umiarkowanych dolegliwościach bólowych. Chory nie zgłaszał wydzielania martwaków kostnych.

W historii choroby leczenie 3 lata temu raka prostaty. Po konsultacji z lekarzem prowadzącym pacjenta zakwalifikowano do leczenia chirurgicznego. Pacjent został przygotowany do zabiegu (odstawiono bifosfoniany, zalecono osłonę antybiotykową).

W znieczuleniu miejscowym oczyszczono ranę (pobrano materiał do badania histopatologicznego $z$ rany), wykonano plastykę wyrostka zębodołowego (powierzchownie oczyszczono odsłonięty wyrostek zębodołowy szczęki, dokonano mobilizacji otaczających tkanek miękkich, szczelnie zaszyto ranę). Po 2 tygodniach pacjent zgłosił się celem zdjęcia szwów. Pacjent pozostaje pod obserwacją od 4 miesięcy, bez objawów wznowy.

\section{Dyskusja}

Najgroźniejszym i zarazem najczęściej opisywanym powikłaniem stosowania bifosfonianów jest martwica kości. Cytowani autorzy są zgodni, że wszystkie zabiegi inwazyjne powinny być wykonywane przed rozpoczęciem terapii bifosfoniana$\mathrm{mi}$. W profilaktyce BRONJ, przed rozpoczęciem terapii z użyciem bifosfonianów należy przeprowadzić sanację jamy ustnej a $w$ trakcie leczenia pacjent powinien dokładnie przestrzegać zasad higieny jamy ustnej, na co szczególnie zwraca uwagę Amerykańskie Towarzystwo Dentystyczne (ang. American Dental Association - ADA). ADA zaleca wprowadzenie zabiegów higienizacyjnych fazy podtrzymującej jako nadrzędnej, przed wprowadzeniem terapii BP. Dodatkowo, co 3-4 miesiące pacjent powinien być kierowany na kontrolne badania stomatologiczne. W przypadku konieczności interwencji stomatologicznej należy w miarę możliwości uwzględnić leczenie endodontyczne zamiast ekstrakcji zębów. Jeśli natomiast zabieg chirurgiczny jest konieczny, należy przeprowadzić go jak najmniej traumatycznie. W przypadku stosowania przez pacjenta uzupełnień protetycznych, zwłaszcza nowych, należy zapobiegać powstawaniu uszkodzeń błony śluzowej wywołanych obecnością protezy [1]. Problem wydaje się być istotny w chwili wystąpienia podejrzenia przerzutu tkanki nowotworowej do kości szczęk. Scoletta proponuje pobierać wycinki do badania histopatologicznego, kiedy istnieje potrzeba wykluczenia przerzutu, kiedy inne metody wykluczenia podejrzenia zostały wyczerpane [1].

\section{Metabolizm kości}

Proces tworzenia tkanki kostnej jest ściśle kontrolowany miejscowo i ogólnoustrojowo. Powyższy proces jest nierozerwalnie związany z gospodarką wapniowo-fosforanową, utrzymaniem właściwości biomechanicznych i wytworzeniem odpowiedniego środowiska dla tworzenia szpiku kostnego. $\mathrm{Na}$ przebudowę wpływają hormony regulujące poziom wapnia, żywienie, wiek, bodźce związane ze wzrostem. Utrzymanie homeostazy tkanki kostnej jest uzależnione od populacji komórek tkanki kostnej których aktywność jest regulowana przez czynniki wzrostu i cytokiny. Czynniki regulujące są sytetyzowane lokalnie lub ogólnoustrojowo, działają autokrynnie, parakrynnie lub endokrynnie. Chociaż przeważająca większość cytokin pochodzi z układu monocytowo-makrofagowego to niektóre $z$ nich sa syntetyzowane przez komórki kości. Czynniki wzrostowe i cytokiny oddziaływują na różnicowanie, replikację i aktywację komórek tkanki kostnej [9]. $\mathrm{Na}$ poziomie molekularnym największą rolę kontrolną wydaje się pełnić szlak RANKL/RANK/OPG, który stanowi punkt $w$ farmakoterapii chorób tkanki kostnej [10]. Odpowiadające za początek przebudowy kości - osteoklasty są komórkami wywodzącymi się linii hematopoetycznej, których różnicowanie jest uzależnione od innych komórek, takich jak komórki zrębu szpiku lub osteoblasty, które wydzielają M-CSF (ang. Macrophage Colony-Stimulating Factor) i RANKL (ang. Receptor Activator Of Nuclear Factor NF- $\kappa \beta$ Ligand) w celu różnicowania i funkcjonowania. W celu wywołania fuzji komórek preosteoklastów w zróżnicowane osteoklasty i ich aktywacji niezbędny jest RANKL [6].

\section{Szlak RANKL/RANK/OPG}

W procesie tworzenia tkanki kostnej niezwykle ważna jest ścisła korelacja między osteoklastami i osteoblastami. W warunkach fizjologicznych kontrola nad przebudową kości warunkowana jest szlakiem RANKL/RANK/OPG, czyli receptor aktywujący jądrowy czynnik NF- $\kappa \beta$ (ang. Receptor Activator Of Nuclear Factor NF- $\kappa \beta$ R - RANK), ligand RANK i osteoprotegeryna (ang. osteoprotegerin OPG). Ligand RANK należący do nadrodziny biatek czynników martwicy nowotworów (ang. Tumor Necrosis Factor - TNF) aktywuje specyficzny receptor zlokalizowany w obrębie preosteoklastów. RANKL jest produkowany przez osteoblasty, komórki śródbłonka i aktywne limfocyty T. Znane są 2 formy RANKL: forma związana z komórkami i forma rozpuszczalna (soluble RANKL, s-RANKL) [16]. Aktwacja szlaku prowadzi do uruchomienia kaskady sygnałów, aktywujących swoiste geny odpowiedzialne za różnicowanie osteoklastów. Działanie RANKL jest równoważone przez roz- 
puszczalny receptor pułapkowy, kompetycyjny (ang. decoy receptor) - osteoprotegerynę. Osteoprotegeryna należy do nadrodziny receptorów czynników martwicy nowotworów (ang. tumor necrosis factor receptor - TNFR). Jej działanie polega łączeniu się z RANKL, na blokowaniu połączenia z RANK, braku aktywacji osteoklastów i hamowaniu resorpcji tkanki kostnej $[6,10,11]$.

\section{Przygotowanie chorego:}

W przypadku konieczności wykonania zabiegów chirurgicznych w obrębie jamy ustnej u chorych przyjmujących bifosfoniany Kan i wsp proponują następujący schemat postępowania [4]:

- Przerwanie terapii BP z konsultacją u onkologa prowadządzego,

- Podanie antybiotyku celem zapobiegnięcia wystąpienia infekcji,

- Sanacja jamy ustnej z naciskiem na minimalnie inwazyjne postępowanie, pierwotne zamknięcie rany, bez nadmiernego napięcia, dokładne oczyszczenie rany w granicach makroskopowo zmienionych tkanek, a w czasie samej procedury - maksymalna oszczędność tkanek otaczających ubytek.

Trudności w ocenie wystąpienia martwicy można dopatrywać się często w zróżnicowanych objawach klinicznych, które mogą manifestować się jako bolesna lub niebolesna zmiana, obrzęk i zapalenie tkanek miękkich, odsłonięty fragment kości. BRONJ może też przebiegać bezobjawowo gdzie choroba zostaje najczęściej wykryta przypadkowo podczas badania radiologicznego kości szczękowych. Czas po jakim pacjenci zgłaszali się do badania był od 4 do 42 tygodni $[1,12]$.

Do tej pory nie ma zgody co do sposobu leczenia i zakresu terapii [12], jak również nie wyjaśniono do końca mechanizmu powstawania BRONJ. Obecnie tłumaczone jest to zahamowaniem metabolizmu kości (ang. turnover) w obrębie szczęk wspótistniejącym z całą kaskadą patologicznych mechanizmów jako odpowiedzi na bodźce [4]. Najczęściej zabiegi skupiające się na leczeniu BRONJ obejmują: poprawienie jakości życia, kontrolę występowania bólu, zapobiegania infekcji, zapobiegania występowaniu nowych ubytków [4, 12]. Występowanie martwicy próbuje się też tłumaczyć blokowaniem angiogenezy, nieprawidłowym modelowaniem kości szczęk, występowaniem stałych mikrourazów, toksycznym wpływem leków na tkanki miękkie oraz infekcji bakteryjnych [6]. BRONJ zdecydowanie częściej występuje u pacjentów stosujących bifosfoniany drogą dożylną niż doustną [6]. Znaczenie mają również dawki bifosfonianów, stąd martwica zdecydowanie częściej pojawia się w leczeniu choroby nowotworo- wej, gdzie dawki są 10 razy większe niż w leczeniu osteoporozy. Podstawowym czynnikiem ryzyka powstania martwicy podczas stosowania bifosfonianów są zabiegi chirurgiczne w obrębie kości szczękowych, najczęściej ekstrakcje zębów [1]. Zdecydowanie rzadziej martwica pojawia się samoistnie. Dodatkowo powstaniu martwicy sprzyja: terapia kortykosteroidami, cukrzyca typu 2, choroba przyzębia, palenie tytoniu, wiek powyżej 60 lat oraz płeć żeńska [6]. Inne czynniki ryzyka to: droga podania, choroby związane z zaburzeniami krzepnięcia, radio- i chemioterapia, sterydoterapia systemowa [4]. Zdecydowana większość przypadków wystąpienia osteonekrozy miała miejsce podczas stosowania bifosfonianów powyżej 2 lat.

Rodzaj stosowanych bifosfonianów wydaje się nie pozostawać bez znaczenia. Jednym z czynników ryzyka podaje się bifosfoniany posiadające atom azotu takie jak kwas zoledronowy. Zjawisko to tłumaczy się mechanizmem ujemnego sprzężenia zwrotnego tlenku azotu na osteoklastogenezę [10].

Inni autorzy próbują tłumaczyć wystąpienie martwicy w czasie terapii bifosfonianami 2 teoriami: inhibicją osteoklastów przy wykorzystaniu bifosfonianów i/lub znacznym osłabieniem metabolizmu w obrębie tkanki kostnej przez wpływ na zmniejszoną angiogenezę [5].

Badania prowadzone przez Scoletta i wsp. ujawniły częstsze występowanie martwicy w obrębie żuchwy $(62,2 \%)$ z czego większość w odcinku tylnym, w szczęce tylko $27 \%$ a u $10,8 \%$ chorych występowała w szczęce i żuchwie, we wszystkich przypadkach w odcinku tylnym. Częstsze występowanie ubytków w żuchwie jest tłumaczone jej słabszym ukrwieniem i cieńszą błoną śluzową [1]. Badania mikroskopowe tkanek zmienionych uwidoczniły puste obszary, bez obecności osteocytów otoczone martwą tkanką kostną (ang. medullary spaces) i tkanką kostną skolonizowaną przez bakterie z grupy Actinomyces (obserwacja w $57 \%$ przypadków). Infekcja bakteryjna nie miała żadnych korelacji [1, 12]. W przeprowadzonych przez siebie badaniach $35 \%$ chorych poddano tylko leczeniu chirurgicznemu po wcześniejszej antybiotykoterapii (10,7\% sekwestromia, 24,3\% powierzchowne czyszczenie rany), $64,9 \%$ miało tylko antybiotykoterapię [1]. U 54\% pacjentów zamknięto odsłoniętą kość tkankami miękkimi. Wszyscy chorzy donieśli o remisji objawów bólowych podczas antybiotykoterapii [1].

Scoletta i wsp. skupił się na porównaniu leczenia chirurgicznego $z$ farmakologicznym. Odradza stosowanie samego leczenia chirurgicznego, gdyż może prowadzić do pogorszenia stanu zdrowia. Przeprowadzone leczenie chirurgiczne poprzedzone leczeniem farmakologicznym daje obiecujące efekty w obserwacji długoterminowej $[1,12]$. 
Scoletta i wsp twierdzi, że leczenie chirurgiczne nie może zapewnić całkowitego wyleczenia, ponieważ cała tkanka jest zmieniona przez stosowane bifosfoniany, w odróżnieniu do martwicy popromiennej, gdzie marginesy tkanki kostnej martwiczej często są bardzo dobrze ograniczone [1, 12].

Chorzy leczeni bifosfonianami często są słabej kondycji życiowej (obciążeni), co utrudnia radykalne postępowanie i długoterminowe, jednoznaczne rokowanie [1, 12]. Bardzo ważnym czynnikiem wyboru metody leczenia jest zastosowanie odpowiedniego leczenia do stanu chorobowego. Stadium I i II jest bardziej podatne na leczenie zachowawcze. W przypadku braku powodzenia w leczeniu zachowawczym należy wdrożyć leczenie chirurgiczne. Leczenie zachowawcze w stadium II i III jest mniej skuteczne w porównaniu do leczenia chirurgicznego. Analizując przypadki należy zwrócić uwagę, że stadium I rzadko dotyka głębszych warstw kości. Stadium II najczęściej penetruje tkankę na większym i głębszym obszarze, przekracza kość zbitą i penetruje do kości gąbczastej. Ukrwienie tkanki gąbczastej jest bardzo ważnym czynnikiem wspomagającym gojenie [4].

\section{Leczenie}

Leczenie martwicy kości związanej z terapią bifosfonianami nie zostało do tej pory ujednolicone. W cytowanym piśmiennictwie spotykamy na różnorodne techniki zabiegowe. Proponuje się dobór zabiegów od stwerdzonego stanu miejscowego i ogólnego [7].

1. zabiegi zachowawcze:

a) leczenie miejscowe:

- miejscowe stosowanie środków bakteriobójczych,

- ozonoterapia,

- laseroterapia,

- komora hiperbaryczna,

- plazma bogatopłytkowa,

b) leczenie ogólnoustrojowe:

- antybiotykoterapia,

- leki rekombinowane,

2. leczenie chirurgiczne:

a) usunięcie w granicach makroskopowo zmienionych tkanek (sekwestromia lub resekcja),

b) powierzchowne oczyszczenie tkanek (tzw odświeżenie rany) celem przygotowania do zabiegów plastycznych (ang. debridement) np: zszycie tkanek.

\section{Stosowanie leków miejscowo działających}

Zwykle stosuje się preparaty przeciwbakteryjne i osłaniające, rzadko jako leczenie niezależne (razem z antybiotykami, miejscowo leczeniem stymulującym gojenie lub leczeniem chirurgicznym).

\section{Farmakoterapia}

Po konsultacji z lekarzem prowadzącym i odstawieniu bifosfonianów można stosować antybiotykoterapię skojarzoną (ampicylina + sulbaktam) z miejscowym stosowaniem leków przeciwbakteryjnych (płukanki z chlorheksydyną) lub $[1,5,13]$.

Protokół leczenia antybiotykiem przewiduje również stosowanie mieszaniny $1 \mathrm{~g}$ amoksycyliny i 250 mg kwasu klawunolowego (ang. amoxycillin/clavulanate potassium) co 8 godzin przez 7 dni lub samej amoksycyliny w dawce $500 \mathrm{mg}$ co 6 godzin [13]. W przypadku wystąpienia objawów miejscowych podczas samej antybiotykoterapii (takie jak czynna przetoka, infekcja) protokół antybiotykoterapii był powtarzany. Jeśli zaistniała potrzeba powtórnego leczenia w okresie krótszym niż 2 miesiące lub występowała alergia na penicylinę - stosowano $600 \mathrm{mg}$ klindamycyny 3 razy dziennie przez 7 dni [1] lub metronidazol w dawce $500 \mathrm{mg}$ co 8 godz [13]. W przypadkach zaostrzeń z pojawieniem się wskazań do stosowania antybiotykoterapii skojarzonej proponuje się ciprofloxacynę $w$ dawce $500 \mathrm{mg}$ co $12 \mathrm{godz}$ lub erytromycynę $\mathrm{w}$ dawce $400 \mathrm{mg}$ co $8 \mathrm{godz} \mathrm{z}$ metronidazolem $\mathrm{w}$ dawce $500 \mathrm{mg}$ co $8 \mathrm{godz}$ [13].

\section{Leczenie chirurgiczne}

Po okresie przygotowawczym leczenia niechirurgicznego chorym proponowano leczenie chirurgiczne polegające na miejscowym oczyszczeniu rany $z$ tkanek martwiczych (ang. debridment) lub częściowej resekcji. Postępowanie obejmowało powierzchowne oczyszczenie rany, sekwestromię lub częściową resekcję w zależności od sytuacji miejscowej $[1,12,14]$.

W zależności od sytuacji miejscowej chorzy byli przyjmowani średnio co 2 miesiące celem kontroli. Podczas takich wizyt, dla potrzeb diagnostycznych, wykonywano fotografię stanu miejscowego oraz stosowne pomiary tkanek zmienionych chorobowo. W zależności od sytuacji miejscowej (przebiegu procesu gojenia) stosowano leczenie uzupełniając (środki odkażające, przyspieszające gojenie) [1, 12].

\section{Ozonoterapia}

W leczeniu martwicy kości proponuje się również stosowanie ozonu medycznego $\left(\mathrm{O}_{3}\right)$. Stosowanie ozonu można podzielić na dwa sposoby: w formie gazowej i w formie zawiesiny. Forma zawiesiny ma swoje zalety, takie jak: mniejsza ilość aplikacji, dokładniejsze aplikowanie, brak obecności cząsteczek toksycznych (tlenków, węglowodorów) [15, 16]. Obie metody wydają się mieć podobne właściwości i efekty terapeutyczne [14-16]. 


\section{Komora hiperbaryczna}

Zwiększenie ciśnienia parcjalnego tlenu powoduje zwiększenie stężenia osteoprotegeryny (OPG) i blokuje tworzenie nowych osteoklastów bez aktywacji receptora RANKL (szlak zależny od stężenia tlenu we krwi) [18]. Większa ilość tlenu wykazująca prefuzję przez tkanki zwiększają tworzenie komórek kościotwórczych. W cytowanych badaniach przyjęto kryterium związanej z odbudową dziąsła (pokrycie odsłoniętej tkanki kostnej) oraz zmniejszenie dolegliwości bólowych. Mechanizm wpływu na regenerację kości nie został jeszcze dokładnie poznany $[14,17,18]$.

\section{Zabiegi kombinowane}

Martins i wsp wykorzystywali antybiotykoterapię, laseroterapię oraz plazmę bogatopłytkową (ang. platelet rich plasma - PRP) jako źródło komórek i czynników wzrostu. Zastosowane metody są bardzo obiecujące [14, 19].

\section{Terapia z wykorzystaniem teryparatydu}

Teryparatyd jest genetycznie rekombinowanym fragmentem parathormonu, powszechnie wykorzystywanym w leczeniu osteoporozy. Jest to jedyny zatwierdzony czynnik anaboliczny zalecony do stosowania w leczeniu osteoporozy, działający przez receptor dla parathormonu stymulujący modelowanie kości, zmniejszający apoptozę osteoblastów, zmniejszającą produkcję sklerostyny przez osteocyty i w ten sposób aktywujący komórki wyścielające (ang. lining cells) [14, 20].

\section{Laseroterapia}

Stosowanie lasera można ograniczyć do technik chirurgicznych oraz biostymulacyjnych [2, 4, 12, 14]. Terapia przy wykorzystaniu laserów niskiej mocy (ang. low-level laser therapy - LLLT) została po raz pierwszy opisana 1975 roku [4]. Technika chirurgiczna przy wykorzystywaniu promieni lasera ma przewage nad metodami konwencjonalny$\mathrm{mi}$, a są to m.in.:

- cięcie metodą bezkontaktową, bez tarcia, przegrzania tkanek, bez innych dodatkowych urazów mechanicznych co ma duży wpływ na wystąpienie martwicy,

- cięcie nie produkuje powstania niepotrzebnych resztek tkankowych (wiórów kostnych),

- powstają miejsca mikro-pęknięć i mikro-eksplozji służących usunięciu tkanek twardych,

- ablacje podczas pracy lasera powodują waporyzację tkanek twardych i przyspieszają usunięcie tkanek,

- uzyskujemy tkankę niezakażoną, odsłoniętą mikrostrukturalną kość wolną od uszkodzenia termicznego.
Doniesienia przeprowadzonych na zwierzętach badań świadczą o bardzo dobrym wpływie na gojenie tkanki kostnej w ciągu 15 dni od wykonania przeszczepu kości [4]. Lasery wykorzystujące niskoenergetyczne promieniowanie są również nazywane „laserami miękkimi”, „laserami terapeutycznymi”, „laserami o niskiej mocy” [2, 4].

Zastosowanie laserów biostymulacyjnych [4, 14]:

- Bezbolesny przebieg gojenia,

- regeneracja tkanek twardych i miękkich w tym tkanki nerwowej,

- przyspieszona proliferacja makrofagów, limfocytów, fibroblastów, komórek śródbłonka i keratynocytów, przyspieszają syntezę kolagenu,

- zwiększenie oddychania na poziomie komórkowym, zwiększenie syntezy ATP, zwiększenie produkcji czynników wzrostu.

\section{Wnioski}

1. Sposób postępowania $z$ chorym $w$ trakcie terapii lekami $z$ grupy bifosfonianów powinien uwzględniać stan miejscowy.

2. W trakcie przygotowywania chorego należy uwzględnić zasadę proporcjonalności, samą procedurę medyczną oraz możliwy do uzyskania efekt terapeutyczny.

3. Ze względu na brak ujednoliconego i usystematyzowanego postępowania terapeutycznego wynik leczenia jest uzależniony od wielu czynników, gdzie kluczowym wydaje się zespołowe przygotowanie i prowadzenie chorego.

\section{Oświadczenia}

Oświadczenie dotyczące konfliktu interesów

Autorzy deklarują brak konfliktu interesów w autorstwie oraz publikacji pracy.

\section{Źródła finansowania}

Autorzy deklarują brak źródeł finansowania.

\section{Piśmiennictwo}

[1] Scoletta M, Arduino PG, Dalmasso P, Broccoletti R, Mozzati M. Treatment outcomes in patients with bisphosphonate-related osteonecrosis of the jaws: a prospective study. Oral Surg Oral Med Oral Pathol Oral Radiol Endod. 2010;110(1):46-53.

[2] Atalay B, Yalcin S, Emes Y, Aktas I, Aybar B, Issever H, Mandel NM, Cetin O, Oncu B. Bisphosphonate-related osteonecrosis: laser-assisted surgical treatment or conventional surgery. Lasers Med Sci. 2011;26:815-23.

[3] Drake MT, Clarke BL, Khosla S. Bisphosphonates: Mechnism of action and role in clinical practice. Mayo Clin Proc. 2008 Sept;83(9):1032-1045.

[4] Kan B, Altay MA, Taşar F, Akova M. Low-level laser therapy supported teeth extractions of two patients receiving IV zolendronate. Lasers Med Sci. 2011;26(5):569-75.

[5] Katsenos S, Christophylakis C, Psathakis K. Osteonecrosis of the jaw in a patient with advanced non-small-cell lung cancer receiving bevacizumab Arch Bronconeumol. 2012;48(6):218-219.

[6] Aghaloo TL, Felsenfeld AL, Tetradis S. Osteonecrosis of the jaw in patient on denosumab. J Oral Maxollofac Surg. 2010;68(5):959-63. 
[7] Ruggiero SL, Dodson TB, Fantasia J, Goodday R, Aghaloo T, Mehrotra B, O'Ryan F. American Association of Oral and Maxillofacial Surgeons Position Paper on Medication-Related Osteonecrosis of the Jaw-2014 Update. J Oral Maxillofac Surg. 2014;72:1938-1956.

[8] Red Kostowski W, Herman Z.S. Farmakologia. Podstawy farmakologii. Leki stosowane w zaburzeniach gospodarki wapniowej. Bifosfoniany. Wydawnictwo Lekarskie PZWL Warszawa. 2010, Wydanie III, tom 1, str 294-297,

[9] Niedźwiedzki T, Kuryszko J.J. Biologia kości. Rozwój kości. Czynniki regulujące przebudowę tkanki kostnej. Wydawnictwo Naukowe PWN Warszawa. 2007, Wydanie I, 56-74,

[10] Pytlik M, Bolek D, Rymkiewicz I. Szlak RANKL/RANK/ OPG w patogenezie chorób - nowe możliwości terapeutyczne. Farm Przegl Nauk. 2009;5:37-42,

[11] Ratajczak M, Sankowicz-Burkiewicz M, Kuczkowski J, Gulida G, Starzyńska A, Gawrońska-Skorkowska J, Włodarkiewicz A, Pawełczyk T. Rola receptora aktywatora jądrowego czynnika kappa $\beta$ (RANKL) oraz osteoprotegeryny (OPG) w rozwoju zębopochodnych torbieli i ziarniniaków okołowierzchołkowych kości szczęki i żuchwy. Nowa Stom. 2013;4:187-190,

[12] Scoletta M, Arduino PG, Reggio L, Dalmasso P, Mozzati M. Effect of low-level laser irradiation on bisphosphonate-induced osteonecrosis of the jaws: preliminary results of a prospective study Photomed Laser Surg. 2010;28(2):179-84.

[13] Marx RE, Sawatari Y, Fortin M, Broumand V. Bisphosphonate-induced exposed bone (osteonecrosis/osteopetrosis) of the jaws: risk factors, recognition, prevention, and treatment J Oral Maxillofac Surg. 2005;63:1567-1575.

[14] Fliefel R, Tröltzsch M, Kühnisch J, Ehrenfeld M, Otto S. Treatment strategies and outcomes of bisphosphonate-related osteonecrosis of the jaw (BRONJ) with characterization of patients: a systematic review. Int $\mathrm{J}$ Oral Maxillofac Surg. 2015;44:568-585,

[15] Agrillo A, Ungari C, Filiaci F, Priore P, lannetti G. Ozone therapy in the treatment of avascular bisphosphonate-related jaw osteonecrosis. J Craniofac Surg. 2007;18(5):1071-1075.
[16] Ripamonti Cl, Cislaghi E, Mariani L, Maniezzo M. Efficacy and safety of medical ozone $(\mathrm{O}(3))$ delivered in oil suspension applications for the treatment of osteonecrosis of the jaw in patients with bone metastases treated with bisphosphonates: preliminary results of a phase I-II study. Oral Oncol. 2011;47:185-190.

[17] Vezzani G, Quartesan S, Cancellara P, Camporesi E, Mangar D, Bernasek T, Dalvi P, Yang Z, Paoli A, Rizzato A, Bosco G. Hyperbaric oxygen therapy modulates serum OPG/RANKL in femoral head necrosis patients J Enzyme Inhib Med Chem. 2017;32(1):707-711.

[18] Freiberger JJ, Padilla-Burgos R, Chhoeu AH, Kraft KH, Boneta O, Moon RE, Piantadosi C.A. Hyperbaric oxygen treatment and bisphosphonate-induced osteonecrosis of the jaw: a case series. J Oral Maxillofac Surg. 2007;65:1321-1327.

[19] Martins MA, Martins MD, Lascala CA, Curi MM, Migliorati CA, Tenis CA, Marques M.M. Association of laser phototherapy with PRP improves healing of bisphosphonate-related osteonecrosis of the jaws in cancer patients: a preliminary study Oral Oncol. 2012;48(1):79-84.

[20] Leder M, Tsai JN, Jiang JA, Lee H. Importance of prompt antiresorptive therapy in postmenopausal women discontinuing teriparatide or denosumab: The Denosumab and Teriparatide Follow-up study (DATA-Follow-up). Bone. 2017;98:54-58.

Zaakceptowano do edycji: 2017-09-01

Zaakceptowano do publikacji: 2017-11-01

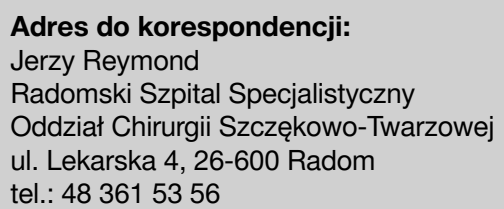

